DOI: $10.21802 / \operatorname{artm} .2019 .4 .12 .92$.

УДК 615.825:616.748+616-071.2-0.57.87

\title{
ПРОГРАМА ФІЗИЧНОЇ ТЕРАПІЇ СТУДЕНТІВ 17-19 РОКІВ 3 ПЛОСКОСТОПІСТЮ І ФУНКЦІОНАЛЬНИМИ ПОРУШЕННЯМИ ПОСТАВИ У ФРОНТАЛЬНІЙ ПЛОЩИНІ
}

\author{
С.П. Наконечна
}

Прикарпатський начіональний університет імені Василя Стефаника, кафедра фізичної терапії, ерготерапї̈, м. Івано-Франківськ, Украӥна,

ORCID ID: 0000-0002-7683-3493,

e-mail:naksvit30@gmail.com

Резюме. У статті представлена програма комплексної фізичної терапії для студентів 17-19 років із плоскостопістю та функціональними порушеннями постави у фронтальній площині. Метою дослідження було визначити нові підходи до фізичної терапії студентів 17-19 років при плоскостопості з функціональними порушеннями постави у фронтальній площині. Для вивчення динаміки основних показників функціонального стану організму у студентів, що мають плоскостопість і сколіотичну поставу, використовували аналіз та узагальнення даних науково-методичної літератури і провідного практичного досвіду фізичної терапії; педагогічне спостереження. Для якісної оцінки ефективності розробленої програми були використані показники біогеометричного профілю постави, окружність грудної клітини, показники функціонального стану хребта і стопи, зовнішнього дихання і функціонального стану серцево-судинної системи, а також методи контролю за станом САС і за параметрами якості ходьби на комп'ютерному комплексі “DIERS FAMUS".

Програма включає три рухових режими: полегшений, полегшено-тренувальний і тренувальний. Вона передбачає використання електростимуляції з метою зміцнення глибоких м'язів спини і гомілки, занять у басейні з теплою водою і глибиною 1,5 м, що включають модифіковані рухливі й спортивні ігри (поло, баскетбол, волейбол) для поліпшення фізичних якостей, пірнальні вправи і дихальну гімнастику Стрельникової для посилення функціонального стану кардіо-респіраторної системи, самомасаж стоп. Програма розроблена для студентів із плоскостопістю з функціональними порушеннями постави у фронтальній площині, у ній використовуються засоби фізичної терапії, що враховують порушення, зумовлені зниженням висоти склепінчастого апарату стопи з поєднаними функціональними деформаціями хребта.

Ключові слова: фізична терапія, плоскостопість, порушення постави, юнацький вік, студенти.

Вступ. Турбота суспільства про молоде покоління є мірилом його культурного і соціального розвитку $[3,4,15]$. За даними МОЗ України, значна кількість молодого населення нашої країни страждає різними порушеннями опорно-рухового апарату (ОРА). Серед цих захворювань найбільшого розповсюдження набули плоскостопість і різноманітні функціональні порушення постави.

Результати дослідження І.П. Випасняка [5], С.I. Лопацького і співав. [10], вказують, що тільки на Прикарпатті більше 45,6\% студентської молоді страждають від такого роду порушень ОРА.

Обгрунтування дослідження. Багато фахівців вказують на тісний зв' язок між станом ОРА i соматичним здоров'ям людини $[1,11]$. Дослідники вважають, що відсутність відхилень в стані хребта $є$ обов'язковою умовою нормального функціонування органів і систем та фізичного розвитку організму в цілому. Ще в древньоіндійских трактатах системи Йога відмічали, що людина починає хворіти тоді, коли гнучкість її хребта зменшується хоча-би на третину [16].

Відомо, що юнацький вік є періодом онтогенезу, який супроводжується суттєвими змінами в діяльності всіх фізіологічних систем: протікають більш напружено енергетичні процеси, суттєвих розвитку зазнає серцево-судинна і дихальна система, зростає м'язова маса, розвивається витривалість, закінчується розвиток рухової координації, змінюється постава [12].

Дослідження вчених свідчать про те, що студенти, які вступають на перший курс вищих навчальних закладів (ВН3), хоча за соматичними показниками віднесені до практично здорових людей, проте вже мають різні функціональні порушення ОРА. До цих порушень у 70,0\% відносяться порушення склепінчастого апарату стопи (САC), і майже у половині випадків $(48,3 \%)$ вони зустрічаються в комплексі 3 функціональними порушеннями постави в сагітальній чи фронтальній площині $[2,8,9]$. Такі дані не викликають особливого здивування, якщо враховувати результати дослідження інших авторів [3, 5], які повідомляють про частоту порушення САC і хребта майже у 50,0\% дітей вже у віці від 5 до 14 років [11]. У зв'язку з цим виникає запитання: чому ці діти з 514 років не були охоплені оздоровчопрофілактичними програмами, які би дозволили зменшити таку кількість майбутніх абітурієнтів 3 порушеннями СAC і хребта на момент поступлення до ВН3?

Відповідь знаходимо в роботах багатьох авторів $[1,6,8,10]$, які серед причин такого катастрофічного положення вбачають дві основні: недостатність коштів та інших матеріальних ресурсів для 
забезпечення реалізації вже існуючих програм 3 фізичної реабілітації, а з іншого боку - у відсутності корекційно-оздоровчих програм 3 фізичної терапії для таких пацієнтів.

Фізичний терапевт - це нова спеціальність, яка тільки недавно внесена до переліку спеціальностей, фахівці з якої готуються на факультетах фізичного виховання і спорту, що підпорядковані $\mathrm{MOH}$ України, але мають право працювати у закладах, які підпорядковані МО3 України [5].

Відповідно до цього корекційно-оздоровчі програми повинні розроблятись та бути адаптовані до переліку специфічних фахових навичок, які притаманні тільки фізичним терапевтам 3 метою максимально широкого їх залучення в якості спеціалістатерапевта для роботи у медичних закладах.

Таким чином, для цих молодих людей з порушенням склепінчастого апарату стопи (САC) i 3 функціональними порушеннями хребта в сагітальній площині потрібні відповідні корекційно-оздоровчі програми, реалізація яких лежить в межах компетентності тільки фізичного терапевта, і які би враховували фізіологічні зміни, характерні для юнацького віку, та наслідки порушення з боку хребта при плоскостопості різного ступеня важкості.

Мета дослідження - визначити нові підходи до фізичної терапії студентів 17-19 років при плоскостопості з функціональними порушеннями постави у фронтальній площині.

Завдання дослідження: розробити структуру і зміст програми фізичної терапії студентів при плоскостопості з функціональними з порушенням постави у фронтальній площині.

Матеріали і методи: аналіз та узагальнення даних науково-методичної літератури i провідного практичного досвіду фізичної реабілітації людей різного віку, що мають плоскостопість і сколіотичну поставу; педагогічне спостереження і вивчення динаміки основних показників функціонального стану організму у цього контингенту при застосуванні заходів фізичної терапії. В якості критеріїв оцінки ефективності розробленої авторської програми були використані показники біогеометричного профілю постави (кут, утворений горизонталлю і лінією, що з'єднує найбільш виступаючу точку лобової кістки і виступ підборіддя; кут, утворений вертикаллю i лінією, що 3'єднує остистий відросток хребця $\mathrm{C}_{7}$ i остистий відросток хребця $\mathrm{L}_{5}$; кут асиметрії лопаток), окружність грудної клітини, показники функціонального стану хребта і стопи (статична силова витривалість відповідних м'язів), зовнішнього дихання (фактична життєва ємкість легень, належна життєва ємкість легень та їх співвідношення) і функціонального стану серцево-судинної системи (ЧСС, індекс Робінсона, проба Руф’є), а також методи контролю за станом CAC i за параметрами якості ходьби на комп'ютерному комплексі “DIERS FAMUS” (Німеччина).

Дослідження проводилися на базі навчальнореабілітаційного центру Прикарпатського національного університету імені Василя Стефаника та облас- ного оздоровчо-спортивного центру “Здоров’я” (м. Івано-Франківськ).

Результати досліджень та їх обговорення. Підбір засобів фізичної терапії та обгрунтування їх використання здійснювалися з урахуванням особливостей організму студентів, їх рухового режиму, протипоказань, спеціальних принципів фізичного виховання, диференціації та індивідуалізації фізичного навантаження, вікових особливостей, компенсаторного напрямку, адекватності, оптимальності і варіативності терапевтичного впливу спеціальних засобів корекції САС і хребта, раціонального поєднання засобів фізичної культури та фізичної терапії.

Програма включає три рухових режими: полегшений, полегшено-тренувальний і тренувальний. Заняття проводилися в полегшеному режимі індивідуальним, а в полегшено-тренувальному і тренувальному - індивідуальним методом і методом малих груп 3 рази на тиждень протягом 24 місяців.

Основною формою рухового режиму було заняття лікувальною водною гімнастикою з переважним застосуванням коригувальних вправ [17]. Перевагу віддавали симетричним фізичним вправам, які усувають асиметрію м'язового тонусу, сприяють корекції асиметрії кутів лопаток, закріплюють навички правильної постави (тричі на тиждень по 45 хв).

Визначальною рисою лікувальної водної гімнастики є застосування фітболів, використання яких сприяе формуванню навички правильної постави, забезпечує зміцнення м'язового корсету і покращує кардіо-респіраторну функцію $[2,16]$.

Для зміцнення глибоких м'язів спини і розвантаження хребта застосовували вправи у басейні 3 теплою водою і глибиною 1,5 м для занять модифікованими рухливими і спортивними іграми (поло, баскетбол, волейбол) з метою поліпшення фізичних якостей.

Для поліпшення функціонального стану органів дихання застосовували пірнання 3 затримкою під водою i парадоксальну дихальну гімнастику А.Н. Стрельникової з метою посилення функціонального стану кардіо-респіраторної системи, яку застосовували після лікувальної гімнастики по 15 хв.

Так як хребет і стопа є єдиною біокінематичною парою, виконання симетричного масажу спини і грудної клітини доповнювали масажем стоп (щодня 10 хв перед ранковою гімнастикою) та масажем стоп у воді за допомогою спеціального обладнання. Посилення дії засобів фізичної терапії доповнювалося курсами фізіотерапії у вигляді електростимуляції м'язів спини і гомілки.

Таким чином, в полегшеному руховому режимі програми, який тривав 2 місяці, застосовували самомасаж стоп, ранкову гімнастику (щодня 15 хв) і ЛФК із застосуванням фітболів (25\% від загальної кількості вправ в основній частині заняття), дихальні вправи за методикою А. Н. Стерельнікової (після лікувальної гімнастики по 15 хв, початковий комплекс), курс масажу спини і грудної клітини (щодня по 20 хв, кількістю 20 процедур).

У полегшено-тренувальному режимі (10 місяців) до вищевказаних засобів вводили вправи на 
профілакторі Євмінова під кутом $15^{\circ}$, поступово збільшуючи до $20^{\circ}$ (50\% від загальної кількості вправ в основній частині, в тому числі з фітболом), курс електротерапії (до застосування масажу, 15 процедур).

У тренувальному режимі програми (12 місяців), крім вище зазначених засобів, вводили вправи у басейні з теплою водою і глибиною 1,5 м для занять модифікованими рухливими і спортивними іграми (поло, баскетбол, волейбол), масаж стоп у воді за допомогою спеціального обладнання, курс масажу спини і грудної клітини (щодня по 20 хв, кількістю 20 процедур).

Дослідження стану опорно-рухового апарату (ОРА) показало, що поширеність функціональних порушень постави у студентів 17-19 років у фронтальній площині становить $35-48 \%$, в сагітальній 49-65\%. Нерідкі у студентів поєднання декількох дефектів постави $(56,8 \%)$ і сплощення поздовжнього склепіння стопи $(36,9 \%)$. Спостереження за педагогічним процесом показало, що переведення учбових занять 3 2-ох півпар по 45 хв кожна в повне заняття протягом 90 хв без перерви між ними привело до того, що сумарний час знаходження студентів 3 неправильною поставою становить 56-65\% часу. Цьому сприяє також відсутність спеціальних рухових хвилинок, що приводить до збільшення загальної втоми і проявляється низьким опусканням голови близько до письмово столу, переважний нахил голови в одну сторону, здавлювання грудної клітки в результаті навалювання тіла на край столу, асиметрія плечей, бічне викривлення хребта, неправильна постановка стоп 3 перенавантаженням переднього відділу і відривом п'яти від підлоги, або навпаки, коли стопа опирається на задній відділ, а пальці опираються на ніжки стільця, що знаходиться спереду.

Встановлено, що студенти недостатньо добре володіють навичками корекції пози. Виконати завдання, що вимагають «прийняти вертикальну позу 3 гарною поставою» i «законспектувати лекцію зберігаючи правильне положення, сидячи за письмовим столом», змогли лише одиниці.

У режимі дня більшість студентів ведуть пасивний вид діяльності, який за обсягом часу значно переважає над активним. Від 6 до 8 годин на день вони перебувають переважно в положенні сидячи, при цьому контроль стану власної постави не здійснюється. Тестування студентів виявило низький рівень знань і навичок організації фізкультурнооздоровчих пауз протягом навчального дня (понад 65\% 3 них не змогли науково обгрунтовано скласти комплекс фізичних вправ оздоровчої спрямованості). Крім того, 20,0\% студентів взагалі порахували, що у них немає на це часу.

Вищесказане визначає необхідність створення умов, що сприяють формуванню правильної постави і вибору засобів корекційно-профілактичної спрямованості на підтримку САС.

Тому наша програма корекції постави і САC передбачає методи педагогічного впливу на процес формування постави: словесні команди, групові установки на збереження правильної пози, індивідуальні зауваження, які необхідні для вироблення рефлексу правильної постави. Причому частота педагогічного впливу за умовами програми повинна бути не менше 4 разів на одне заняття. На 25 і 75 хвилинах заняття необхідно проводити фізкультурні хвилинки, що включають вправи на вдосконалення функції рівноваги і корекції тіла в просторі, збільшення сили і правильного розподілу тонусу м'язів, що утримують хребет у вертикальному положенні, розтягувальні та силові вправи з корекцією вертикалі хребта з симетричним навантаженням на м'язи передньої, задньої і бічних поверхонь тіла.

У результаті проведеного дослідження після завершення колекційної програми 77\% першокурсників мали поліпшені характеристики постави. Поліпшення стану сагітальних вигинів нами зафіксовано у $32 \%$ студентів 17-19 років. Зміцнення “м'язового корсета" призвело до симетричної активності м'язів правої і лівої сторони тулуба, що підтверджується результатами оцінки симетрії плечового пояса. Асиметрія плечей і кутів лопаток зменшилася на 2,1-2,4 см у 23\% і на $0,8-1,5$ см у $38,5 \%$ студентів. Крім того, у 14\% студентів нами зафіксовано вперше їх симетричне розташування. Зовнішня ознака постави (відхилення хребта від вертикалі у вихідних положеннях стоячи і сидячи) зменшилася у $23 \%$ студентів. У показниках навички підтримки правильної пози і їі корекції в просторі спостерігалася вірогідна позитивна динаміка $(\mathrm{P}<0,05)$. Час перебування студентів 3 неправильною поставою під час заняття зменшилася до $44 \%(\mathrm{P}<0,02)$.

Встановлено, що після виконання фізичних вправ на заняттях наступні 5-10 хвилин 66\% студентів виконували завдання 3 правильним положенням хребта. Тестування статичної витривалості м'язів i координації рухів також виявило позитивну динаміку. Показники силової витривалості м'язів черевного преса збільшилися 312 раз до 23 раз (Р $<0,01)$, м'язів спини - в 1,4 рази. Відсоток сплощення САС при $100 \%$ навантаженні маси власного тіла зменшився у $24 \%$ студентів, а силова витривалість м'язів стопи - на $10 \%(\mathrm{P}<0,05)$. Таким чином, дотримання перерахованих вище умов протягом навчального дня сприяє більш ефективному освоєнню навички підтримки правильної пози під час конспектування чи інших письмових завдань, формуванню правильної постави, збільшення рухового режиму, досягненню оздоровчого і профілактичного ефекту. Ці дані знаходять підтвердження в роботах інших авторів [7, $13,14]$.

\section{Висновки:}

1. Проблема формування і підтримки постави вимагає дотримання відповідних умов і комплексу профілактичних заходів, що застосовуються безпосередньо в навчальній діяльності. Позитивні зрушення в показниках шийного і поперекового лордозів, асиметрії плечей, кутів лопаток, силової витривалості м'язів стопи доводять ефективність запропонованих умов формування постави і підтримки САС у навчальній діяльності. Результати експерименту підтверджують доцільність використання фізкультурних хвилинок на заняттях, які тривають 90 хв, як частини практичних заходів терапевтичного впливу на процес формування постави. 
2. Розроблена програма для студентів із плоскостопістю 3 функціональними порушеннями постави у фронтальній площині використовує засоби фізичної терапії, що враховують порушення, спровоковані зниженням висоти склепінчастого апарату стопи та поєднаними функціональними деформаціями хребта. В якості критеріїв оцінки ефективності фізичної терапії рекомендується використовувати комплекс показників, що характеризують функціональний стан м'язів, які відповідають за ортоградне положення тіла, показники біогеометричного профілю постави і стопи, а також стану кардіореспіраторної системи та якості ходьби.

Наступні дослідження визначатимуть ефективність запропонованої програми фізичної терапії для функціонального стану стопи і хребта, серцевосудинної, дихальної систем студентів із плоскостопістю та порушенням постави у фронтальній площині.

\section{References:}

1. Aloshyna AI, Petrovych VV. Suchasni pidkhody do korektsii bioheometrychnoho profiliu postavy shkoliariv. Visnyk Chernihivskoho natsionalnoho pedahohichnoho universytetu. Seriia: Pedahohichni nauky. Fizychne vykhovannia ta sport.2015; 129(1):3-10.

2. Bybyk RV. Korektsiia porushen postavy zhinok pershoho zriloho viku zasobamy ozdorovchoho fitnesu [avtoreferat]. Kyiv; 2013. P.19.

3. Bodnar O. Osoblyvosti bioheometrychnoho profiliu postavy ditei 5-6 rokiv. Sportyvnyi Visnyk Prydniprovia. 2005; 2:102-104.

4. Vashchenko LV, Badohyna LP, Ravlynko AA, Rubashnaia OF. Detskaya invalidnost $\mathrm{i}$ invalidnost $\mathrm{s}$ detstva kak mediko-soczialnaya problema. Zdorove rebenka. 2008; 2:14-18.

5. Vypasniak IP. Teoretyko-metodychni zasady korektsiino-profilaktychnykh tekhnolohii $\mathrm{z}$ fizychnoho vykhovannia studentiv $\mathrm{z}$ funktsionalnymy porushenniamy oporno-rukhovoho apparatu. Molodizhnyi naukovyi visnyk Skhidnoievropeiskoho natsionalnoho universytetu imeni Lesi Ukrainky. 2018; 29:21-28.

6. Gagara VF, Onischuk IV. Metody korrekczii osanki studentov sredstvami fizicheskikh uprazhnenij. Pedagogika, psihologiya i mediko-biologicheskie problemyi fizicheskogo vospitaniya i sporta. 2012; 7:43-46.

7. Zaytseva TN, Kulikov AG, YArustovskaya OV. Skolioz u detej: novye podkhody k lecheniyu i reabilitaczii. Voprosyi kurortologii, fizioterapii i lechebnoy kulturyi. 2017; 4:43-47.

8. Kashin AD. Skolioz i narushenie osanki: lechebnaya fizkultura $\mathrm{V}$ sisteme mediczinskoj reabilitaczii. Minsk: NMTSentr; 2000. P.240.

9. Kashuba VA, Lazareva EB, Kozlov YUV. Soderzhanie tekhnologii fizicheskoj reabilitaczii detej 5-6 let so skolioticheskoj osankoj, s nefiksirovanny`mi narusheniyami oporno-dvigatel nogo apparata, $v$ usloviyakh doshkol nogo uchebnogo zavedeniya. Uchebnie zapiski BGUFK. 2014; 2:23-30.

10. Lopatskyi S, Vypasniak I, Vintoniak O, Zaborniak S. Analiz korektsiino-profilaktychnykh tekhnolohii vykorystovuvanykh u protsesi fizychnoho vykhovannia studentiv $\mathrm{z}$ funktsionalnymy porushenniamy opornorukhovoho apparatu. Visnyk Prykarpatskoho natsionalnoho universytetu imeni Vasylia Stefanyka. 2016; 23:3.

11. Potapchuk AA, Didur MD. Osanka i fizicheskoe razvitie detej. Programmy' diagnostiki i korrekczii narushenij. Sankt-Peterburg: Rech; 2001. P.166.

12. Skinder LA, Gerasevich AN, Polyakova TD, Pankova MD. Fizicheskaya reabilitacziya detej s narusheniyami osanki i skoliozom: uchebno-metodicheskoe posobie]. Brest: BrGU; 2012. P.210.

13. Terenteva OS, Popov RYU, Syisoev AN, Bogdanov MYU. Etiologiya i diagnostika narushenij osanki u studentov. Vestnik Tambovskogo universiteta. Seriya: Gumanitarnyie nauki. 2012; 112(8):196-202.

14. Thor LK. Zdorov'esberegayushhie tekhnologii kak faktor sokhraneniya zdorov'ya studentov. Pedagogika i sovremennost. 2013; 4:102-107.

15. Shchyrba VA. Prychyny, profilaktyka ta korektsiia porushen postavy u ditei molodshoho shkilnoho viku. Teoriia ta metodyka fizychnoho vykhovannia. 2016; 3:28-35.

16. Kashuba V., Nosova N., Kolomits T., Kozlov Yu. Control of the state of the biogeometric profile of posture of a person doing physical exercises. Sport Herald of the Dnieper. 2017; 2:183-190

17. Marinho DA, Fahl LB, Neiva HP. The effects of water exercise on physical fitness and health parameters. CPQ Orthopaedics. 2019; 3:1-3.

\section{УДК 615.825:616.748+616-071.2-0.57.87 \\ ПРОГРАММА ФИЗИЧЕСКОЙ ТЕРАПИИ СТУ- ДЕНТОВ 17-19 ЛЕТ С ПЛОСКОСТОПИЕМ И ФУНКЦИОНАЛЬНЫМИ НАРУШЕНИЯМИ ОСАНКИ ВО ФРОНТАЛЬНОЙ ПЛОСКОСТИ}

\section{С.П. Наконечная}

Прикарпатский национальный университет имени Василия Стефаныка, кафедра физической терапии, эрготерапии, г. Ивано-Франковск, Украина, ORCID ID: 0000-0002-7683-3493,

e-mail:naksvit30@gmail.com

Резюме. В статье представленная программа комплексной физической терапии для студентов 1719 лет с плоскостопием и функциональными нарушениями осанки во фронтальной плоскости. Целью исследования было определить новые подходы к физической терапии студентов 17-19 лет при плоскостопии с функциональными нарушениями осанки во фронтальной плоскости. Для изучения динамики показателей функционального состояния организма у студентов, что имеют плоскостопие и сколиотическую осанку, использовали анализ и обобщение данных научно-методической литературы и ведущего практического опыта физической терапии; педагогическое наблюдение. Для качественной оценки эффективности разработанной программы были использованы показатели биогеометрического профиля осанки, окружность грудной клетки, показатели функционального состояния позвоночника и стопы, внешнего 
дыхания и функционального состояния ССC, а также методы контроля состояния CAC и по параметрам качества ходьбы на компьютерном комплексе "DIERS FAMUS".

Программа включает три двигательных режима: облегченный, облегченно-тренировочный и тренировочный. Она предусматривает использование электростимуляции с целью укрепления глубоких мышц спины и голени, занятий в бассейне с теплой водой и глубиной 1,5 м, включая модифицированные подвижные и спортивные игры (поло, баскетбол, волейбол) для улучшения физических качеств, нырятельные упражнения и дыхательную гимнастику Стрельниковой для усиления функционального состояния кардио-респираторной системы, самомасаж стоп. Программа разработана для студентов с плоскостопием и функциональными нарушениями осанки во фронтальной плоскости, она использует средства физической терапии, которые учитывают нарушения, предопределенные снижением высоты сводчатого аппарата стопы и сопутствующими функциональными деформациями.

Ключевые слова: физическая терапия, плоскостопие, нарушение осанки, юношеский возраст, студенты.

\section{UDC 615.825:616.748+616-071.2-0.57.87 PHYSICAL THERAPY PROGRAM FOR STUDENTS AGED 17-19 YEARS WITH FLAT- FOOTEDNESS AND FUNCTIONAL DISORDERS OF POSTURE IN THE FRONTAL PLANE}

\section{S.P. Nakonechna}

Vasyl Stefanyk Precarpathian National University, Department of physical therapy, ergotherapy, Ivano - Frankivsk, Ukraine, ORCID ID: 0000-0002-7683-3493, e-mail:naksvit30@gmail.com

Abstract. The article presents the program of complex physical therapy for students of 17-19 years with flat feet and functional disorders of posture in the frontal plane. The purpose of the research was to identify new approaches to the physical therapy of students 17-19 years old with flat feet and functional disorders of the posture in the frontal plane. For studying the dynamics indicators of the functional state of the body used the analysis and summarization of scientific and methodological literature and leading practical experience of physical therapy of people of all ages, with flat feet and scoliotic posture; pedagogical observation. For qualitative evaluation of the developed author's program were used: indicators of biogeometric profile of the posture, chest circum- ference, indicators of the functional state of the spine and foot, external respiration and functional state of the cardiovascular system, as well as methods of monitoring the status of VFA and parameters of walking quality on the DIERS FAMUS computer complex (Germany).

The program includes three movement modes: lightweight, lightweight training and training. The program involves the use of electrical stimulation to strengthen the deep back and lower leg muscles, training in the pool with warm water 1.5 meters deep for training modified motive and sports games (polo, basketball, volleyball) to improve physical abilities, diving exercise and respiratory gymnastics of Strelnikova to enhance the functional state of the cardio-respiratory system, selfmassage of the feet. It was found that after completing the correction program, $77 \%$ of students had improved posture characteristics. Improvements in sagittal flexion were observed in $32 \%$ of students aged $17-19$. Strengthening of the "muscular corset" led to symmetrical activity of the muscles of the right and left sides of the torso, which is confirmed by the results of the evaluation of the symmetry of the shoulder girdle. Asymmetry of shoulders and shoulder blades decreased by $2.1-2.4 \mathrm{~cm}$ in $23 \%$ and by $0.8-1.5 \mathrm{~cm}$ in $38.5 \%$ of students. In addition, symmetrical arrangement was recorded in $14 \%$ of students. External sign of posture (deviation of the spine from the vertical in the initial position of standing and sitting) decreased in $23 \%$ of students. Indicators of the skill of maintaining the correct posture and correction in space showed probable positive dynamics. The length of time of student's stay with improper posture during class decreased to $44 \%$. The problem of formation and maintenance of posture requires observance of the appropriate conditions and complex of preventive measures applied directly in educational activity. Positive shifts in indicators of cervical and lumbar lordosis, asymmetry of the shoulders, angles of the shoulder blades, and strength endurance of the muscles of the foot prove the effectiveness of the proposed conditions of posture formation and support of VFA in training program. For students with flat feet with functional disorders of the posture in the front plane uses the developed means of physical therapy, taking into account the disorders caused by the lowering of the height of the vaulted apparatus of the foot and associated with it functional deformations of the spine. As criteria for evaluating the effectiveness of physical therapy, it is recommended to use a complex of indicators that characterize the functional state of the muscles responsible for the orthographic position of the body, indicators of the biogeometric profile of the posture and the status of the cardio-respiratory system and walking quality.

Keywords: physical therapy, flat feet, scoliotic posture, adolescence, students.

Стаття надійшла в редакцію 12.11.2019 р. 